\title{
Investigation on Current Situation of Students in University of Sino-foreign Cooperative Education and Its Countermeasures of Management Improvement
}

\author{
Hao Feng \\ School of Humanity and Law \\ Northeastern University \\ Shenyang, China 110819 \\ School of Humanity and Law \\ Shenyang University \\ Shenyang, China 110044
}

\author{
Wanbing Shi \\ School of Humanity and Law \\ Northeastern University \\ Shenyang, China 110819
}

\begin{abstract}
It has significant value for students in colleges of Sino-foreign cooperative education through investigation on current situation of them and exploration on countermeasures of improving management. Research methods like questionnaire method, induction method and statistical analysis method are applied to investigate the current situation of students in colleges of Sino-foreign cooperative education, reveal existing problems and reasons and propose targeted countermeasures to improve student management in colleges of Sino-foreign cooperative education, making for the improvement of student management level and the promotion of development in Sino-foreign cooperative education.
\end{abstract}

Keywords-colleges of Sino-foreign cooperative education; investigation on current situation of students; problems; student management; improvement countermeasures

\section{INTRODUCTION}

In recent years, with the constant acceleration of internationalization of higher education, our country advocates Sino-foreign cooperative education. It stipulates in national medium and long-term plan for educational reform and development, "It is the basic state policy of our country to strengthen international exchange and cooperation: carry out multilayer and extensive educational exchange and cooperation to improve the internationalization level of education." [1] By the end of 2016, there are 597 colleges for Sino-foreign cooperative education, accounting for 20 percent of the total number of colleges in our country. University of 211 Project accounts for 16 percent of the total number of colleges for Sino-foreign cooperative education. Besides, among the 34 provinces, municipalities and autonomous regions, except for Xinjiang, Tibet and Qinghai, the others have implemented. [2] However, with the soaring development of Sino-foreign cooperative education, the student management pattern as an important part of higher education management still march on the spot and become backward increasingly, seriously influencing and restricting the healthy and ordered implementation of Sino-foreign cooperative education. Therefore, researches on student management pattern under Sino-foreign cooperative education have become important topic of higher education development. Valuable exploration has been carried out to establish student management pattern applicable to Sinoforeign cooperative education through reference and integration of excellent educational resources at home and abroad.

\section{INVESTIGATION ON CURRENT SITUATION OF STUDENTS IN COLLEGES OF SINO-FOREIGN COOPERATIVE EDUCATION AND PROBLEM ANALYSIS}

\section{A. Investigation on Current Situation of Students in Colleges of Sino-Foreign Cooperative Education}

1) Investigation on age structure and educational background structure of students in colleges of Sino-foreign cooperative education: Ninety-seven teachers and students in colleges of Shenyang carry out questionnaire survey on age structure and educational background structure of students in colleges of Sino-foreign cooperative education. The investigation results are as follows "Fig. 1" and "Fig. 2":

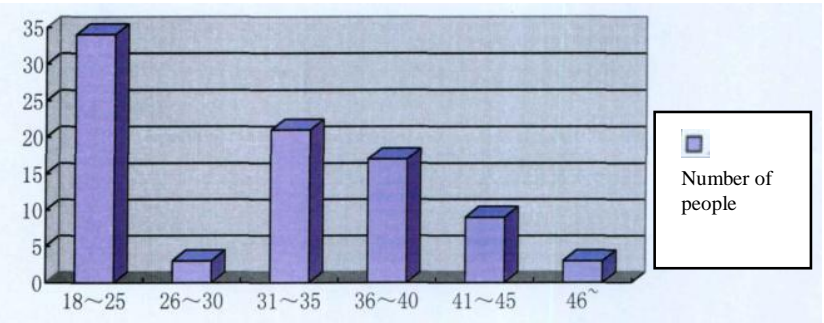

Fig. 1. Age structure of respondents 


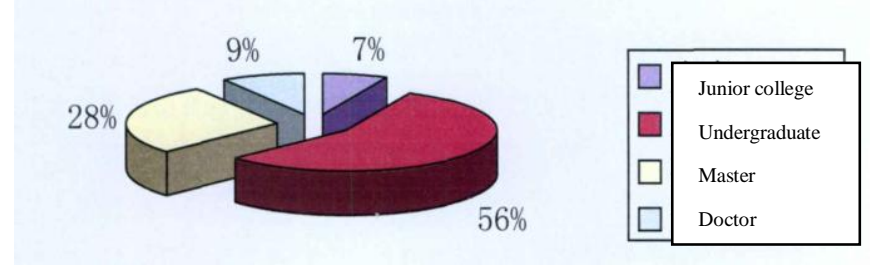

Fig. 2. Educational background structure of respondents

It is found in the above figures that the student management under the pattern of Sino-foreign cooperative education is implemented among undergraduates. The current system of student management should be provided for undergraduates. However, the student management system in some schools is unclear. They fail to know how to solve problems and randomly formulate rules and regulations without consider the reality of undergraduates, leading to repeated curriculum provision and lacking consistency between courses. It causes consumption and waste of resources [3]. According to the characteristics of Sinoforeign cooperative education, because wide differences exist between countries, cross-cultural management becomes great challenge of student management. Many schools do not establish a systematic and effective student management system to solve this problem. It is also an important problem for colleges and institutions.

2) Investigation on mental state of students in colleges of Sino-foreign cooperative education: Because of different natures and patterns of school running, students enrolled in Sino-foreign cooperative educational institutions differ from students of parent universities. They bear greater mental stress embodying in: 1. Environmental pressure. Because students in schools of Sino-foreign cooperative education come from well-off families, they receive better education than ordinary students, so that they often form a sense of superiority. However, when students with similar "status" are integrated, the sense of loss replaces the sense of superiority. 2. Compared with students of parent universities, these students need to bear dual pressures from language learning and professional learning within the same time, meanwhile, must accept and adapt to two different teaching systems including different styles of textbook compilation, teaching methods and assessment methods. 3. Most of these students are the only child from wealthy families. Because of being cared by parents excessively for a long time, they have strong self-centeredness. They have weak ability in self-reliance and self-care and bearing setbacks. They will at a loss when facing setbacks. The extreme inadaptability in social contacts boosts their mental pressure. The great pressure makes these students depressed in the bottom of life. These problems bring great resistance for student management. It increases difficulty in student management at the meantime obviously reduces the effects of collective activities in colleges.

3) Investigation on current situation that students in colleges of Sino-foreign cooperative education are influenced by network: According to an internet survey from China Internet Network Information Center, internet users between 18 and 30 and having college degree and above account for 85.98 percent and 84.67 percent among the Chinese internet users respectively. According to a sampling survey of Tsinghua University, the internet access rate of college students reaches 88 percent. The average internet access rate of college students is so high let alone this rate of students under the pattern of Sino-foreign cooperative education. It is more convenient for student under this pattern to contact the internet or enjoy the first hand resources introduced from abroad and carry out international exchange. However, problems will appear in this process. For example, under the overall background of economic globalization, international hostile forces never give up implementing the "peaceful evolution" strategy on socialist countries. Nowadays, they focus on young students. Because students under the pattern of Sino-foreign cooperative education have more active mind and stronger receptivity than ordinary students, under the invasion of western civilization, students' traditional thinking model will be greatly impacted. Besides, foreign teachers intentionally or unintentionally pass on their ideologies to students like "individualistic heroism", "theism" and "Capital". These concepts advocate self-centeredness, having adverse effects on students under the pattern of Sinoforeign cooperative education, especially those with immature thoughts. The bad effects include serving the time, forgetting friendship for profit, selfishness and narrowness. In other words, the westernized ideology conflicts with socialist core value system. Therefore, it is important to let students properly use internet and make the best use of the circumstances in student management.

\section{B. Existing Problems of Students in Colleges of Sino- Foreign Cooperative Education and Reason Analysis}

At present, because Sino-foreign cooperative education programs require examination and approval of the Ministry of Education, most are expansively enrolled students within the plan. Like other ordinary undergraduates, they come from senior high schools. Therefore, they have essential features of full-time students and unique features different from full-time students because of good family condition and training directions.

1) Weak knowledge base and learning ability, big differences in learning attitude: Because the enrollment mark of specialty in Sino-foreign cooperative education is low, the students enrolled differ from other undergraduates in basis, learning ability and learning initiative. The most prominent problem is English. These students have weak English basis. English is the "foundation" for students in Sino-foreign cooperative education programs. Therefore, these students have great pressure in professional learning. Furthermore, some students drop out of school because they totally fail to adapt to bilingual education and English textbooks. From the perspective of students' purpose in 
choosing Sino-foreign cooperative education, they want to study abroad. They have power basic cultural knowledge, clear purpose and work hard. Some students only pursue diploma and qualified course assessment, and have no interest in studying abroad and learning knowledge. Only a few of students want to experience college life and disregard learning. Different purposes and attitudes toward learning in colleges also make the teaching and student management more difficult.

2) Strong self-esteem and weak self-discipline ability: Because students have to pay expensive tuition in this program, they come from wealthy families and most are the only child. They are spoiled and pursue higher living level. Growing up in this environment, these students are selfcentered and have strong desire in self-expression, poor understanding of organizational discipline. They only value feelings and interests of their own, lack correct understanding and constraints of themselves, and have weak self-discipline consciousness. Some students are afraid of difficulties and fail to effectively manage spare time. They play games and see movies in spare time. It will have adverse impact on life and learning and even cause tragedy if these problems cannot be solved timely.

3) Great learning stress and psychological burden: Compared with students of ordinary colleges, students under the pattern of Sino-foreign cooperative education have to meet the requirement of foreign language level of going abroad and obtain scores of major courses specified by the foreign side before education. Students have compact course arrangement, full contents and clear objectives. It brings severe tests for students with weak basic knowledge. These students fail to understand the course so they will have a sense of repression and failure even give up on themselves. Meanwhile, parents also hope students can learn in foreign schools in cooperative education to obtain foreign diploma. The learning stress and expectations from families make students have overweight psychological burden and have unhealthy emotions like anxiety and depression.

\section{COUNTERMEASURES TO IMPROVE STUDENT MANAGEMENT IN COLLEGES OF SINO-FOREIGN COOPERATIVE EDUCATION}

The effects of student management under the pattern of Sino-foreign cooperative education influence the survival and development of Sino-foreign cooperative education and school-running quality and the sustainable development of colleges. Therefore, it is extremely urgent to improve the efficiency of student management under the pattern of Sinoforeign cooperative education. The following countermeasures can be adopted:

\section{A. Combine Chinese and Western Elements and Accumulate Experience in System of Sino-Foreign Cooperative Education}

The pattern of Sino-foreign cooperative education in our country is at the initial stage, and the existing experience and the corresponding student management system are immature. Therefore, in order to establish scientific and reasonable management system, we must combine Chinese and western elements. Relevant departments should boldly refer to overseas developed experience and combine with the reality of their own. The core of student management system is "people". "People first" is emphasized in Scientific Outlook on Development. The theory on school management in western developed countries is "student-oriented and serviceoriented". [4] Student management should satisfy and serve all students with different gifts, requirements, purposes and individuality. Besides, they should "look inward". In other words, the student management cannot do without the work of administrators in student management. Administrators in student management should have ability in student management, high enthusiasm for work and even language competence and communication skills. The stipulation should be included in investigation systems of student management. Sino-foreign cooperative education aims at training students with international view and broad horizon. Therefore, student supervisors should boldly bring in experienced foreign teachers to teach or carry out academic exchange in schools or institutions. Meanwhile, we have to bring in talent training system and curriculum plan of foreign colleges, especially the curriculum plan of undergraduates. Professional courses are taught by full-time foreign teachers. Schools can strengthen the research on basic theories and rules of student management and list the research as a task in the plan to support excellent student supervisors and guarantee with the system of Sino-foreign cooperative education. It will greatly improve the enthusiasm of student supervisors and promote the development of systems.

\section{B. Strengthen Scientific Guidance to Solve Students' Mental Problems}

Under the background of Sino-foreign cooperative education, students' mental problems are an important challenge for student supervisors, directly relating to students' mental state. Therefore, student supervisors especially instructors must guide students to establish correct world outlook, outlook on life and values. Students should be trained to use Marxism-Leninism and materialistic dialectics to resist the temptation of material interests. The theoretical contents of socialist core value system must exist in students' thoughts. Activities like Poetry Festival, Debate Competition and Life Lecture are taken to let students consciously realize the importance of socialism, patriotism and collectivism and be sentimentally attached to Chinese culture. They should use aesthetic education to guide students in the pursuit of the true, the good and the beautiful. In the moral cultivation, guide students to identify the value of foreign elements like overseas politics, economy, culture and life style inevitably brought by Sino-foreign cooperative education. Student supervisors can let students watch advertising video and visit the development history of the school, in order to let students feel the school spirit, establish closeness with the school and trigger students' true emotions for the school. Moreover, use the spirit of teachers in forging ahead in unity to stimulate students to pursue excellent. As mentioned above, most students under this background have superior living 
conditions and they do not suffer from setbacks. Therefore, problems may appear when they face setbacks. Under this circumstance, the behaviors of college teachers are distinctly important because it influences students all the time. They should value noble teacher's ethics and use rigorous and serious attitude toward academic research, dedicated attitude in education to influence students. [5] It can help students to bottom out. Students transform the stress in severe environment into inexhaustible impetus to overcome difficulties in learning and life and pursue excellence. It is the key to solve students' spiritual problem.

\section{Exploit the Advantages of Network to the Full and Improve Service Efficiency}

Student supervisors must take the initiative to grasp new technology of the network and use network to publicize. "If Marxism does not occupy the ideological field, non-Marxism and anti-Marxism will occupy." [6] At the same time, student supervisors should build Campus Network to spread traditional excellent Chinese culture and excellent foreign cultural achievements, give full scope to the theme of the times and exert positive energy. We should open the ideological, intellectual and interesting network ideological and political education position, timely grasp students' change of thoughts and participate in the discussion of hot issues and guide information effectively. Meanwhile, we can provide online courses related to Chinese and western moral principles and excavate the common points in order to organically combine with them and make them harmony and unity. Of course, we have to adjust measures to local conditions according to the national conditions. In order to better and more effectively use network resources, colleges invite psychological experts and legal experts as counselors to strengthen internet legal education and network safety education of college students. Instead of mechanically closing negative topics on the network, we can design some problems that concern students' benefits and arouse their interests to distract students' attention, use healthy and progressive topics to attract their attention. Unhealthy and unstable elements are contained in the bud. To sum up, student supervisors should seize the principle direction of network culture on campus. In this way, we can use the modernized and convenient tool of network and exert its efficiency.

\section{CONCLUSION}

We must narrow the gap between developed countries and us in education and strengthen international exchange and cooperation for survival and development of higher education. Cooperation in running schools is the inexorable trend of education internationalization. [7] Sino-foreign cooperative education is distinctly different from parent universities. The student work should not completely follow the existing work pattern of parent universities. Of course, we should research and explore the rule of student work under the Sino-foreign cooperative education, constantly deepen reform and bring in advanced teaching methods and educational resources from abroad. At the meantime, the facts of schools and institutions should be closely combined.
Follow the principle of teaching students in accordance with their aptitude and adjusting measures to local conditions, proceed from the reality and seek truth from facts, in order to improve the effectiveness of work and promote the development of Sino-foreign cooperative education. With the economic development, the scientific and technological level improves increasingly and the school reform is deepened. We firmly believe that the student management under Sinoforeign cooperative education is promising.

\section{REFERENCES}

[1] The Ministry of Education of the People's Republic of China, Regulations on Sino-foreign Cooperative Education of the People's Republic of China, 2003, 22

[2] Dong Tao. Necessity to Advance Sino-foreign Cooperative Education [J], the Science Education Article Collects, 2014(290):11

[3] Zhang Kangkang. Research on Teaching Management in Institutions of Sino-foreign Cooperative Education [D], Shanghai: East China Normal University, 2010:23

[4] Schuh, J . \&Jones, R, Student Services ---- A Handbook for the Profession(5thed)[M].San Francisco: Jossey-Bass A Wiley Imprint, 2011

[5] Paige, M. \& Mestenhauser, J. (1999, October). Internationalizing educational administration. Educational Administration Quarterly, 35(4), 500-517.

[6] Gao Jinling. Theory and Practice--Modern School Management Based on Democracy and Efficiency [M], Guilin: Guangxi Normal University Press, 2006(4). 21

[7] Qian Jingwei. Discussion on Sino-foreign Cooperative Education [J], Journal of Southwest University for Nationalities: Humanities and Social Science, 2005(3): 17. 